\title{
Do GH, IGF-I and oxytocin interact by regulating the secretory activity of porcine ovarian cells?
}

\author{
A V Sirotkin, A V Makarevich, H B Kwon ${ }^{1}$, J Kotwica ${ }^{2}$, J Bulla \\ and L Hetényi \\ Research Institute of Animal Production, 94992 Nitra, Slovakia \\ 'Department of Biology, Chonnam National University, Kwangju 500-757, South Korea \\ ${ }^{2}$ Institute of Animal Reproduction and Food Research, 10-718 Olsztyn-Kortowo, Poland \\ (Requests for offprints should be addressed to A V Sirotkin, Research Institute of Animal Production, Hlohovská 2, 94992 Nitra, Slovakia; \\ Email: sirotkin@vuzv.sk)
}

\begin{abstract}
The aims of this study on porcine ovarian granulosa cells were to examine the effect of $\mathrm{GH}$ on oxytocin $(\mathrm{OT})$, IGF-I and IGF-I receptors, IGF-binding protein-3 (IGFBP-3), progesterone and prostaglandin E (PGE), as well as to determine whether IGF-I and/or OT may be mediators of GH action. The cells were cultured either with porcine $\mathrm{GH}(\mathrm{pGH})(1 \mathrm{ng} / \mathrm{ml}$ to $10 \mu \mathrm{g} / \mathrm{ml}$ or $100 \mathrm{ng} /$ $\mathrm{ml}$ only), antiserum against IGF-I $(0 \cdot 1 \%)$, antiserum against $\mathrm{OT}(0 \cdot 1 \%)$ or a combination of $\mathrm{GH}(10 \mathrm{ng} / \mathrm{ml})$ with antiserum against IGF-I or antiserum against OT $(0 \cdot 1 \%)$. The secretion of IGF-I, OT, IGFBP-3, progesterone and PGE was determined using RIA/IRMA, whilst the IGF-I binding sites were measured using a radioreceptor assay.

It was observed that pGH increased the secretion of IGF-I and the abundance of IGF-I binding sites in granulosa cells. Furthermore, GH inhibited OT release, stimulated progesterone and PGE output, but had no
\end{abstract}

significant effect on IGFBP-3 secretion. Immunoneutralization of IGF-I by antiserum against IGF-I inhibited PGE secretion, but it did not influence progesterone or IGFBP-3 secretion. Binding of OT by antiserum suppressed IGFBP-3, PGE, but not progesterone secretion. Neither immunoneutralization of IGF-I nor OT substantially prevented the effects of $\mathrm{GH}$ on progesterone, IGFBP and PGE.

These observations demonstrate the involvement of GH, IGF-I and OT in the control of porcine ovarian secretory activity and the ability of GH to regulate IGF-I and OT production and IGF-I reception. Nevertheless, lack of correlation between the effects of $\mathrm{GH}$, antiserum against IGF-I and antiserum against OT, as well as the inability of blockade of IGF-I or OT to prevent the effects of GH, suggests that IGF-I and OT, despite their dependence on $\mathrm{GH}$, do not mediate $\mathrm{GH}$ action on ovarian cells. Journal of Endocrinology (2001) 171, 475-480

\section{Introduction}

Growth hormone (GH) appears to be a regulator of reproductive processes (for reviews see Franks 1998, Schams et al. 1999, Hull \& Harvey 2000). The involvement of GH in the control of ovarian function is confirmed by the presence of $\mathrm{GH}$ receptors on ovarian cells (Kirby et al. 1996, Schams et al. 1999), and by their ability to respond to $\mathrm{GH}$ with changes in proliferation, apoptosis, oocyte maturation, secretion of hormones and growth factors, and production of gonadotrophin receptors (Spicer \& Echternkamp 1995, Samaras et al. 1996, Franks 1998, Sirotkin et al. 1998, Lucy et al. 1999, Schams et al. 1999). Although these effects have been described in a range of species, pig granulosa are known only to exhibit the effects of GH on insulin-like growth factor-I (IGF-I) and steroid hormones (Spicer \& Echternkamp 1995, Samaras et al.
1996). The actions of $\mathrm{GH}$ on other ovarian substances (IGF-binding proteins (IGFBPs), oxytocin (OT), receptors for IGF-I) have not been described. The first aim of this study was to confirm the action of GH on IGF-I and progesterone secretion, and to examine the effect of $\mathrm{GH}$ on receptors for IGF-I, and on OT, IGFBP-3 and prostaglandin E (PGE) release by porcine ovarian granulosa cells.

The local mediators of GH action on ovarian function are not completely understood. There is evidence that GH can influence the reproductive system through both IGFI-dependent and IGF-I-independent mechanisms (Hull \& Harvey 2000). The GH-induced increase in IGF-I and OT secretion, and the similarity of some effects of $\mathrm{GH}$, IGF-I and OT on ovarian cells (women: Sirotkin \& Schaeffer 1995; cow: Spicer \& Echternkamp 1995, Sirotkin 1995, Sirotkin \& Makarevich 1999, Sirotkin et al. 
Table 1 Characteristics of immunoassays

Specificity

(cross-reactivity)

\section{Assay}

IGF-I

Progesterone

OT

IGFBP-3

PGE OT
$<1.9 \%$ to IGF-II, $<0.01 \%$ to insulin, proinsulin, $<0.001 \%$ to EGF, pGH, OT, progesterone, oestradiol

$<0.001 \%$ to cortisone, corticosterone, cortisol, androstenediol, pregnenolone, oestradiol, testosterone

$<0 \cdot 005 \%$ to arg-vasopressin, $<0.04 \%$ to lys-vasopressin, $17 \%$ to arg-vasotocin, $22 \%$ to des-OT

$<0.03 \%$ to IGFBP-1, $-2,-4,-5,-6$, IGF-I, $-\mathrm{II}, \mathrm{pGH}, \mathrm{pLH}, \mathrm{pFSH}$,

$<28.0 \%$ to PGA- $1,<7 \cdot 0 \%$ to PGA-2, $<0.6 \%$ to PGB- $1,<1 \cdot 4 \%$

to PGB-2, $<5 \cdot 0 \%$ to PGF- $1,<1 \cdot 5 \%$ to PGF-2, $165 \%$ to PGE- 1 , $100 \%$ to PGE-2

\section{Sensitivity}

(ng/ml)

$0 \cdot 34$

$0 \cdot 12$

$0 \cdot 0035$

$0 \cdot 5$

$0 \cdot 015$
Coefficient of variation (\%)

\begin{tabular}{|c|c|}
\hline Intra-assay & Interassay \\
\hline$<10 \cdot 0$ & $<18 \cdot 0$ \\
\hline$<13 \cdot 1$ & $<8 \cdot 0$ \\
\hline$<9 \cdot 0$ & $<5 \cdot 0$ \\
\hline$<3.9$ & $<1.9$ \\
\hline$<7.5$ & $<4 \cdot 0$ \\
\hline
\end{tabular}

$\mathrm{EGF}=$ epidermal growth factor; $\mathrm{pLH}=$ porcine luteinizing hormone; $\mathrm{pFSH}=$ porcine follicle-stimulating hormone.

2000; pig: Spicer \& Echternkamp 1995, Samaras et al. 1996, Sirotkin et al. 1998, Lucy et al. 1999, Schams et al. 1999), provide indirect evidence that IGF-I and OT may be mediators of $\mathrm{GH}$ action on the ovary. On the other hand, the differences in the effects of GH, IGF-I and OT on ovarian secretory activity, apoptosis and oogenesis (sheep: Wathes et al. 1995; rodents: Apa et al. 1994, 1996, Chun et al. 1996, Hsueh et al. 1996; cow: Kirby et al. 1996, Izadyar et al. 1997; pig: Sirotkin et al. 1998), together with the absence of GH stimulation of IGF-I in sheep and bovine ovaries (Wathes et al. 1995, Kirby et al. 1996, Lucy et al. 1999) suggest that GH action is probably not mediated by IGF-I or OT. There is no direct evidence for the involvement of IGF-I and OT in the mediation of $\mathrm{GH}$ effects on ovarian cells. Such evidence would be the action of GH on IGF-I and OT and the prevention of GH action on substances, other than IGF-I and OT, after IGF-I and OT blockade. The second aim of our study was to determine, by immunoneutralization, whether IGF-I and/or OT may be mediators of $\mathrm{GH}$ action on progesterone, IGFBP-3 and PGE release by porcine ovarian cells.

\section{Materials and Methods}

Preparation, culture and processing of granulosa cells

Granulosa cells were aspirated from 3-6 mm diameter follicles from the ovaries of non-ovulated Slovakian white improved gilts (10 months of age, immediately before the start of sexual cyclicity), after slaughter at a local abattoir, and processed as described previously (Sirotkin 1995).

Granulosa cells $\left(1 \times 10^{6}\right.$ cells $\left./ \mathrm{ml}\right)$ were cultured in $2 \mathrm{ml}$ DMEM/Ham's F-12 1:1 mixture supplemented with 10\% bovine fetal serum and 1\% antibiotic-antimycotic solution (all from Sigma Chemical Co., St Louis, MO, USA) in Falcon 24-well plates (Becton Dickinson, Lincoln Park, NJ, USA) at $37{ }^{\circ} \mathrm{C}$ under $5 \% \mathrm{CO}_{2}$ in humidified air. After
2 days of pre-culture the medium was replaced with medium of the same composition. Control groups contained either no cells (blank control) or cells but no exogenous hormones or drugs. Experimental groups received immunological grade porcine GH (pGH) (USDApGH-B-1; provided by Dr J A Proudman, USDA Animal Hormone Program, Beltsville, MD, USA).

The effects of $\mathrm{GH}$ on the secretion of IGF-I and OT was tested at 1, 10, 100, 1000 or $10000 \mathrm{ng} \mathrm{GH} / \mathrm{ml}$. The effect of $\mathrm{GH}$ on other secretions was tested at $100 \mathrm{ng} / \mathrm{ml}$, based on previous observations (Sirotkin et al. 1998, Sirotkin \& Makarevich 1999). Other experimental groups were treated with rabbit antiserum against IGF-I, kindly provided by Dr A F Parlow (National Hormone and Pituitary Program, Harbor-UCLA Medical Center, Torrance, CA, USA), rabbit antiserum against OT, kindly provided by Prof. A P F Flint (University of Nottingham, Sutton Bonington, Leics, UK), both as $0 \cdot 1 \%(1: 1000)$ solutions in culture medium, alone or in combination with pGH $(100 \mathrm{ng} / \mathrm{ml})$.

The immunological activity of $\mathrm{GH}$ and the two antisera at the concentrations used were previously evaluated by RIAs (partial data in Table 1). Solutions $(0 \cdot 1 \%)$ of antisera against IGF-I and OT were able to block $72-80 \%$ of respective ligand in the medium. All treatments were dissolved in culture medium immediately before experiment. After 2 days of culture, the medium was gently aspirated and frozen at $-18{ }^{\circ} \mathrm{C}$ to await RIA. The cell monolayer was immediately subjected to radioreceptor assay (RRA). Cell number and viability were determined by Trypan Blue staining and haemocytometer counting. No statistically significant differences in these indices between control and experimental groups were observed.

\section{Immunoassay}

Concentrations of IGF-I, OT and PGE were determined in $25-100 \mu$ incubation medium by RIA as described 


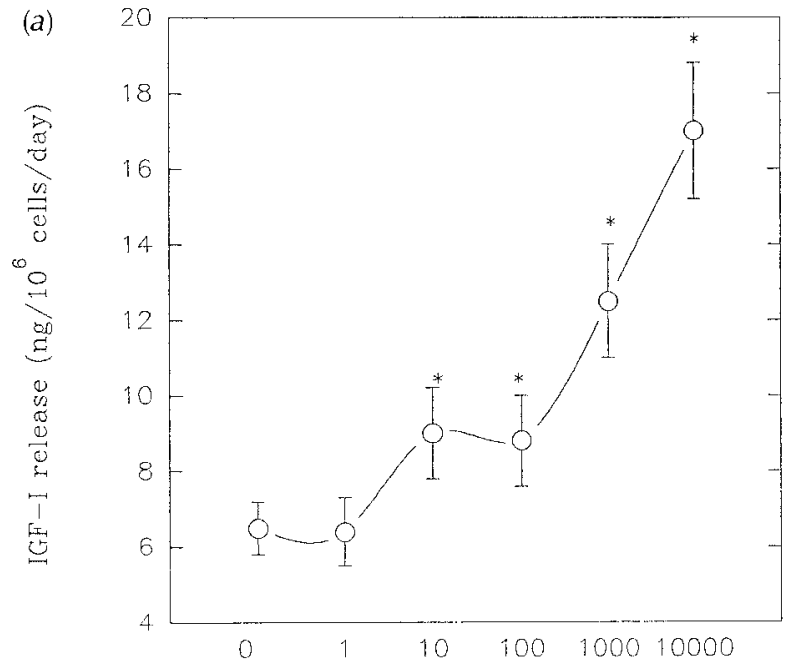

Preparation dose added (ng/ml medium)

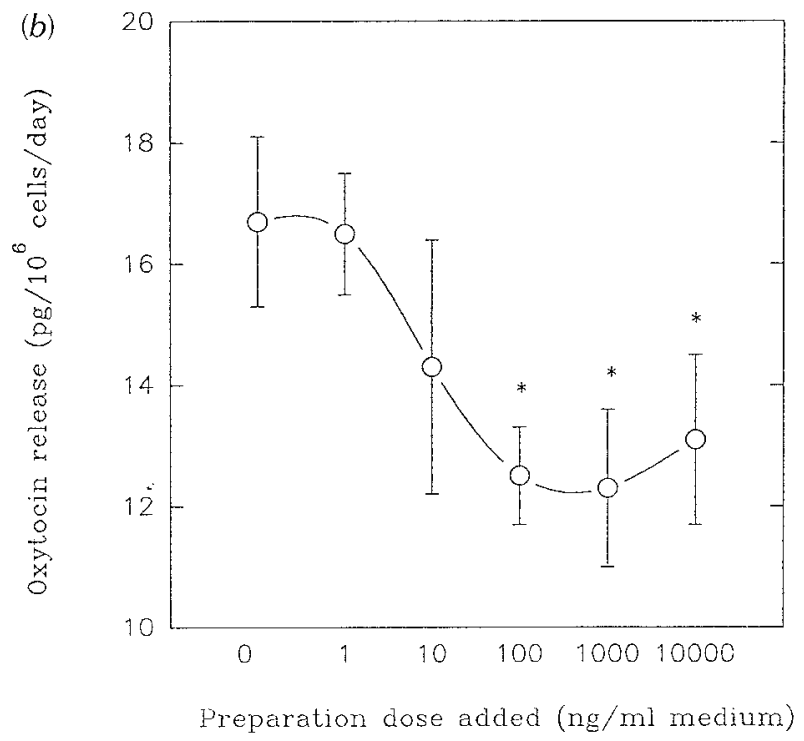

Figure 1 Effect of pGH $(0,1,10,100,1000$ or $10000 \mathrm{ng} / \mathrm{ml})$ on (a) IGF-I and (b) OT secretion by cultured porcine granulosa cells (RIA/IRMA data). Values are means \pm S.E.M. ${ }^{*}$ Significant difference $(P<0 \cdot 05)$ compared with control (medium without addition).

previously (Kotwica \& Skarzynski 1993, Chang et al. 1995, Makarevich \& Sirotkin 1999). Progesterone and IGFBP-3 were assayed using RIA/IRMA kits from DSL (Webster, TX, USA) according to the manufacturer's instructions. RIA for IGF-I and IGFBP-3 included an extraction procedure to break the IGF-I/IGFBP complex. All RIA/IRMAs were validated for use in samples of culture medium. Assay characteristics are presented in Table 1.

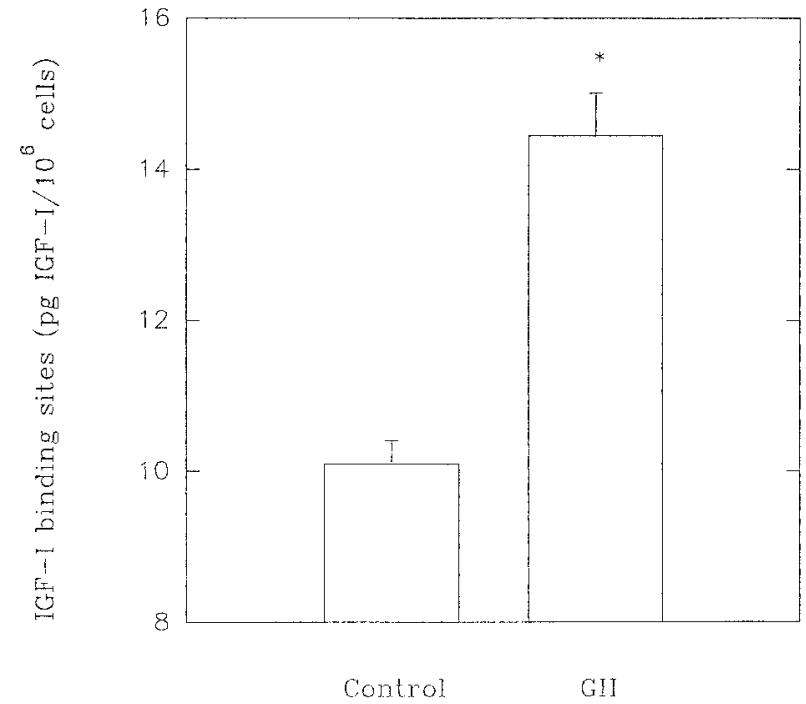

Figure 2 Effect of pGH (100 ng/ml) on expression of IGF-I binding sites in cultured porcine granulosa cells (RRA data). Values are means \pm S.E.M. * Significant difference $(P<0 \cdot 001)$ compared with control (medium without addition).

\section{$R R A$}

IGF-I binding sites in cell monolayers were determined by RRA (Linge \& Green 1993). Immediately after culture, the cells were rinsed in $2 \mathrm{ml}$ cold PBS and exposed for $3 \mathrm{~h}$ at $4{ }^{\circ} \mathrm{C}$ to ${ }^{125} \mathrm{I}-\mathrm{IGF}-\mathrm{I}$ (350 000 c.p.m./well), produced in our laboratory by radiolabelling of recombinant human (rh) IGF-I (Sigma) (Makarevich \& Sirotkin 1999). They were rinsed again three times with cold PBS, lysed with $100 \mu \mathrm{l} 0 \cdot 1 \mathrm{M} \mathrm{NaOH}$, and the radioactivity of the lysate measured. Non-specific binding of ${ }^{125} \mathrm{I}$ was assessed by exposing the cells to ${ }^{125}$ I-IGF-I together with excess $(0.5 \mu \mathrm{g} /$ well $)$ of rhIGF-II (Sigma). Non-specific binding did not usually exceed $12 \%$ of the specific binding.

\section{Statistics}

Each experimental group was represented by four culture wells. Assays of hormone and growth factor content in incubation medium were performed in duplicate. The data shown are means of values obtained in three separate experiments performed on separate days using separate pools of granulosa cells, each obtained from 20-40 animals. For RIA/IRMA, the values of blank controls (medium cultured without the cells) were subtracted from the values determined in cell-conditioned medium. In RRA, the values of non-specific binding were subtracted from specific binding values. Amounts of hormone secreted and numbers of IGF-I receptors were calculated per $10^{6}$ viable cells/day. Significant differences in RIA and RRA data between experiments were evaluated using two-way ANOVA. When effects of treatments were revealed, data 
(a)

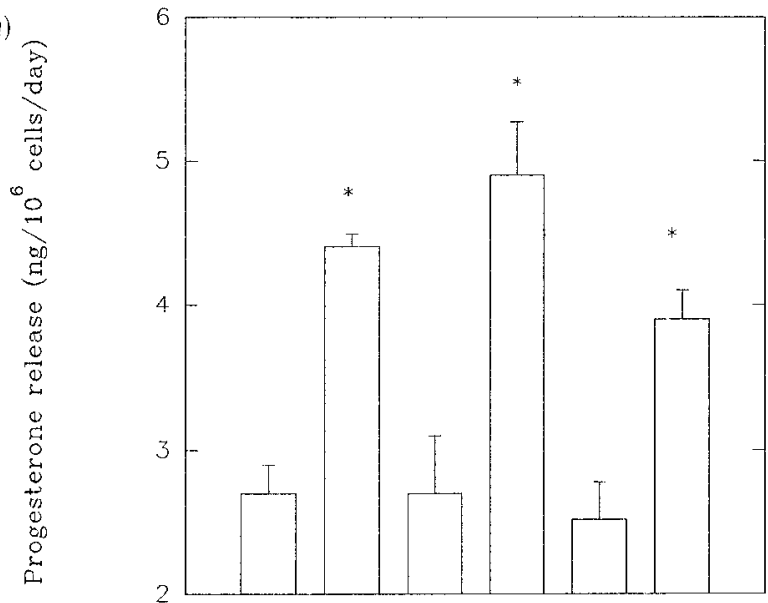

(b)

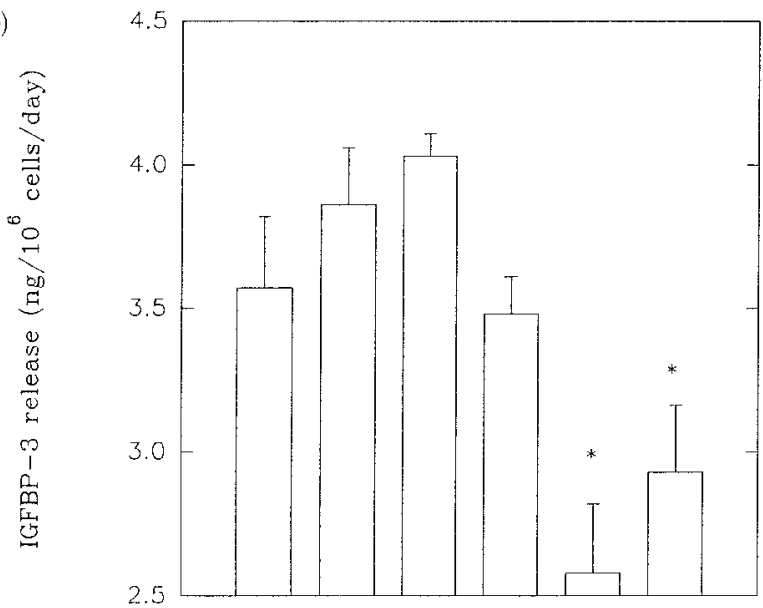

(c)

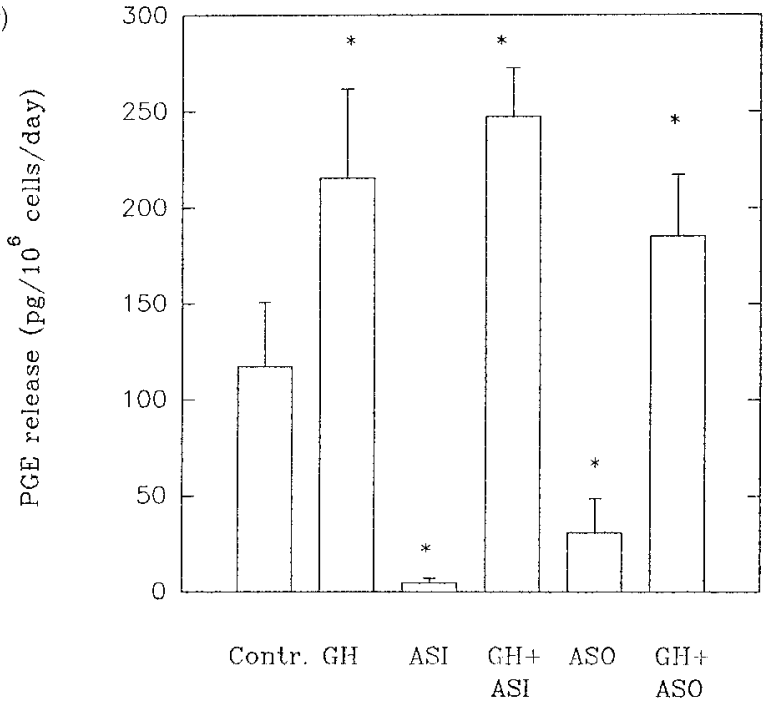

Journal of Endocrinology (2001) 171, 475-480 were compared by Duncan's multiple range test. The coefficients of variation of replicates within each group did not exceed 18\%. Differences from control with $P<0 \cdot 05$ were considered as significant.

\section{Results}

Analysis of porcine granulosa cells and cell-conditioned medium showed that these cells secreted significant amounts of IGF-I, OT, progesterone, IGFBP-3 and PGE, and possessed IGF-I binding sites.

Addition of $\mathrm{GH}$ to the incubation medium at concentrations of $0 \cdot 01-10 \mu \mathrm{g} / \mathrm{ml}$ induced a significant $(P<0 \cdot 05$ at 10 and $100 \mathrm{ng} / \mathrm{ml}, P<0.001$ at 1 and $10 \mu \mathrm{g} / \mathrm{ml}$ ) increase in IGF-I secretion at all but the lowest concentration (Fig. $1 a$ ). Addition of $\mathrm{GH}$ at $100 \mathrm{ng} / \mathrm{ml}$ or more significantly reduced OT secretion $(P<0 \cdot 05$; Fig. $1 b)$. Furthermore, this treatment significantly $(P<0 \cdot 001)$ enhanced the number of IGF-I binding sites (Fig. 2). The secretion of progesterone was significantly stimulated by $\mathrm{GH}$ $(P<0 \cdot 001)$ (Fig. 3a).

Antisera against IGF-I or OT did not affect basal or $\mathrm{GH}$-stimulated progesterone secretion, although there was a slight reduction $(P<0 \cdot 05)$ in GH-stimulated progesterone secretion in the presence of antiserum against OT (Fig. 3a). There was no significant effect of $\mathrm{GH}$ or antiserum against IGF-I on the concentration of IGFBP-3. Antiserum against OT significantly $(P<0 \cdot 05)$ reduced IGFBP-3 secretion in both the presence and the absence of GH (Fig. 3b).

GH significantly $(P<0 \cdot 05)$ enhanced PGE secretion. Antisera against IGF-I and OT both inhibited $(P<0 \cdot 001$ and $P<0.05$ respectively) basal PGE secretion but did not affect GH-stimulated PGE secretion (Fig. 3c).

\section{Discussion}

The data presented in Figs 1 and 3 confirm previous reports (Spicer \& Echternkamp 1995, Samaras et al. 1996, Sirotkin et al. 1998) on the production of IGF-I, OT, IGFBP-3, progesterone and PGE by porcine ovarian cells. However, this is probably the first demonstration of OT secretion by cultured porcine granulosa cells. Figure 2 represents the first evidence for the existence of receptors for IGF-I in porcine ovarian cells. The measured IGF-I binding sites are probably IGF-I receptors rather than

Figure 3 Effect of pGH $(100 \mathrm{ng} / \mathrm{ml})$, antiserum against IGF-I (ASI $0 \cdot 1 \%$ ), antiserum against OT (ASO, $0 \cdot 1 \%$ ) and combination of $\mathrm{pGH}$ $(10 \mathrm{ng} / \mathrm{ml})$ with antiserum against IGF-I $(0 \cdot 1 \%)(\mathrm{GH}+\mathrm{ASI})$ and against OT $(0 \cdot 1 \%)(\mathrm{GH}+\mathrm{ASO})$ on (a) progesterone, (b) IGFBP-3 and (c) PGE release by cultured porcine granulosa cells (RIA/IRMA data). Values are means \pm S.E.M. ${ }^{*}$ Significant difference $(P<0 \cdot 05)$ compared with control (medium without additions). 
IGFBPs on the cell surface, because these and previous data show that cultured porcine ovarian cells produce relatively little IGFBP (Sirotkin et al. 1998), which is unable to bind significant amounts of IGF (Makarevich \& Sirotkin 1999).

The actions of antisera against IGF-I and OT on ovarian secretory activity (Fig. 3), which in general are opposite to the effects of IGF-I and OT themselves, confirm previous reports on the involvement of IGF-I (Spicer \& Echternkamp 1995, Franks 1998, Sirotkin et al. 1998, Lucy et al. 1999, Schams et al. 1999) and OT (Wathes 1989, Sirotkin et al. 1996, 1998) in controlling ovarian secretory activity. The differential effects of antisera against IGF-I and OT on IGFBP-3 (but not on progesterone or PGE) suggest that IGF-I and OT may in some cases influence the ovary independently of each other.

Our observations of GH effects on IGF-I (Fig. 1a) and progesterone (Fig. 3a) correspond to previous reports of $\mathrm{GH}$ action on growth factor and steroid secretion by porcine granulosa cells (Spicer \& Echternkamp 1995, Samaras et al. 1996). This appears to be the first report of an action of GH on IGFBP-3, OT and PGE secretion, as well as on receptors to IGF-I, in porcine granulosa cells.

The actions of GH on IGF-I and IGF-I binding sites suggest that GH can activate the intraovarian IGF-I system at different sites including secretion and receptor availability. This observation suggests that in pigs as in other species, GH may affect the ovarian IGF-I/IGFBP system. However, in contrast to cattle (Sirotkin \& Makarevich 1999) the mechanism appears not to involve IGFBP-3.

Our data suggest that $\mathrm{GH}$ is a potent regulator of secretion of other ovarian substances, for example OT, steroids and PGs. They agree with our previous observations of GH effects on OT, steroid and PGE secretion by isolated ovarian follicles (Sirotkin et al. 1998).

Analysis of the effects of GH on IGF-I and OT, as well as of the effects of GH and antisera against IGF-I and OT on progesterone, IGFBP-3 and PGE, provides evidence that IGF-I and OT do not mediate the actions of GH on ovarian substances other than IGF-I and OT. First, differences in the dose-response curves of IGF-I and OT, as well as the contrasting effects of GH on IGF-I and OT secretion, indirectly suggest the existence of multiple $\mathrm{GH}$ receptors and/or second messenger systems allowing independent control of IGF-I and OT. Secondly, the opposing effects of GH on IGF-I and OT secretion, the lack of correlation between effects of $\mathrm{GH}$ and antisera against IGF-I and OT (especially on IGFBP-3 and PGE), as well as the inability of antisera against IGF-I and OT to prevent GH action, strongly suggest that IGF-I and OT do not mediate the effects of $\mathrm{GH}$ on the porcine ovary. Thus, GH controls porcine ovarian progesterone, IGFBP-3 and PGE secretion but probably not through local IGF-I and OT. Other mechanisms for this action have been proposed (Kirby et al. 1996, Schams et al. 1999).
In our studies we attempted to examine whether $\mathrm{GH}$ affects IGF-I and OT, whether GH, IGF-I and OT are involved in control of other ovarian substances (progesterone, IGFBP-3, PGE), and whether GH affects these substances via IGF-I and OT. Taken together, our data demonstrate (i) the involvement of GH, IGF-I and OT in the control of porcine ovarian secretory activity, (ii) the ability of GH to influence IGF-I and OT production and reception, and (iii) that $\mathrm{GH}$ effects are not mediated by IGF-I or OT.

\section{Acknowledgements}

We express our gratitude to Dr J A Proudman for kindly providing $\mathrm{pGH}$, Dr A F Parlow for the gift of antiserum against IGF-I, Prof. A P F Flint for kindly providing the antiserum against $\mathrm{OT}$, as well as to Mrs $\mathrm{K}$ Tothová, $\mathrm{M}$ Blahová, Ž Kuklová and B Ustianovská for technical assistance, and Dr M R Luck (University of Nottingham, UK) for editing the manuscript.

\section{References}

Apa R, Lanzone A, Miceli F, Caruso A, Mancuso S \& Canipari R 1994 Growth hormone induction of rat granulosa cell tissue plasminogen activator expression and progesterone synthesis. Molecular and Cellular Endocrinology 99 153-159.

Apa R, Caruso A, Andreani CL, Miceli F, Lazzarin A, Manstrandrea M, Ronsisvalle E, Mancuso S \& Lanzone A 1996 Growth hormone stimulates androsterone synthesis by rat theca-interstitial cells. Molecular and Cellular Endocrinology 118 95-101.

Chang KJ, Kim JW, Lee J, Im W-B, Kwon HB \& Schuetz AW 1995 Prostaglandin production and ovulation during exposure of amphibian ovarian follicles to gonadotropin or phorbol ester in vitro. General and Comparative Endocrinology 100 257-266.

Chun SY, Eisenhauer KM, Minami S, Billig H, Perlas E \& Hsueh AJ 1996 Hormonal regulation of apoptosis in early antral follicles: follicle-stimulating hormone as a major survival factor. Endocrinology 137 1447-1456.

Franks S 1998 Growth hormone and ovarian function. Baillieres Clinical Endocrinology and Metabolism 12 331-340.

Hsueh AJ, Eisenhauer K, Chun SY, Hsu SY \& Billig H 1996 Gonadal cell apoptosis. Recent Progress in Hormone Research 51 433-455.

Hull KL \& Harvey S 2000 Growth hormone: a reproductive endocrineparacrine regulator? Reviews of Reproduction 5 175-182.

Izadyar F, Van Tol HT, Colenbrander B \& Bevers MM 1997 Stimulatory effect of growth hormone on in vitro maturation of bovine oocytes is exerted through cumulus cells and not mediated by IGF-I. Molecular Reproduction and Development 47 175-180.

Kirby CJ, Thatcher WW, Collier RJ, Simmen FA \& Lucy MS 1996 Effects of growth hormone and pregnancy on expression of growth hormone receptor, insulin-like growth factor-I, and insulin-like growth factor binding protein-2 and -3 genes in bovine uterus, ovary and oviduct. Biology of Reproduction 55 996-1002.

Kotwica J \& Skarzynski D 1993 Influence of oxytocin removal from the corpus luteum on secretory function and duration of estrous cycle in cattle. Journal of Reproduction and Fertility 97 411-417.

Linge C \& Green MR 1993 Determination of growth factor receptor distribution by immunocytochemistry or autoradiography, and quantification by ligand binding or FACS analysis. In Growth 
Factors. A Practical Approach, pp 201-236. Eds I McKay \& I Leigh. Oxford, New York, Tokyo: IRL Press of Oxford University Press

Lucy MC, Bilby CR, Kirby CJ, Yuan W \& Boyd CK 1999 Role of growth hormone and maintenance of follicles and corpora lutea. Journal of Reproduction and Fertility 54 (Suppl) 49-59.

Makarevich AV \& Sirotkin AV 1999 Development of a sensitive radioimmunoassay for IGF-I determination in samples from blood plasma and cell-conditioned medium. Veterinarni Medicina 44 71-78.

Samaras SE, Channing SF, Barber JA, Simmen FA \& Hammond JM 1996 Regulation of insulin-like growth factor I biosynthesis in porcine granulosa cells. Endocrinology 137 4657-4664.

Schams D, Berisha B, Kosmann M, Einspanier R \& Amselgruber WM 1999 Possible role of growth hormone, IGFs, and IGF-binding proteins in the regulation of ovarian function in large farm animals. Domestic Animal Endocrinology 17 279-285.

Sirotkin A 1995 Direct action of growth hormone on bovine ovarian cells: effects on estradiol, oxytocin, vasopressin secretion by granulosa cells and on oocyte maturation and cleavage in vitro. Annales d'Endocrinologie 57 219-224.

Sirotkin AV \& Makarevich AV 1999 GH regulates secretory activity and apoptosis in cultured bovine granulosa cells through the activation of the cAMP/protein kinase A system. Journal of Endocrinology 163 317-327.

Sirotkin A \& Schaeffer H-J 1995 The effect of growth hormone on secretory activity of human granulosa cells in vitro. Endocrinology and Metabolism 2 215-220.
Sirotkin A, Schaeffer H-J, Mlyncek M, Missik J \& Bulla J 1996 Oxytocin affects the secretion of steroids, insulin-like growth factor-I, prostaglandin F2 and cyclic nucleotides by human granulosa cells in vitro. Human Reproduction 11 152-155.

Sirotkin AV, Makarevich AV, Kotwica J, Marnet P-G, Kwon HB \& Hetenyi L 1998 Isolated porcine ovarian follicles as a model for the study of hormone and growth factor action on ovarian secretory activity. Journal of Endocrinology 159 313-321.

Sirotkin AV, Makarevich AV \& Hetenyi L 2000 Effect of growth hormone and inhibitors of protein kinase A on IGF-I, oxytocin and progesterone secretion by cultured bovine granulosa cells. Annales d'Endocrinologie 61 154-158.

Spicer LJ \& Echternkamp SE 1995 The ovarian insulin-like growth factor system with an emphasis on domestic animals. Domestic Animal Endocrinology 12 223-245.

Wathes DC 1989 Oxytocin and vasopressin in the gonads. Oxford Reviews of Reproductive Biology 11 226-283.

Wathes DC, Perks CM, Davis AJ \& Denning-Kendall PA 1995 Regulation of insulin-like growth factor-I and progesterone synthesis by insulin and growth hormone in the ovine ovary. Biology of Reproduction 53 882-889.

Received 27 July 2001

Accepted 21 August 2001 